\title{
Knapping before and after polishing: Technological evidence in the Neolithic polished stone tools from Hungary
}

\author{
Elisabetta Starnini ${ }^{1}$, György Szakmány ${ }^{2}$ \\ 1. Department of Civilizations and forms of Knowledge, University of Pisa. Via dei Mille 19, 56126 Pisa, Italy. \\ Email: elisabetta.starnini@unipi.it \\ 2. Department of Petrology and Geochemistry, Eötvös Loránd University, Pázmány Péter sétány 1/c, H-1117 \\ Budapest, Hungary. Email: gyorgy.szakmany@geology.elte.hu
}

\begin{abstract}
:
The authors present the evidence gathered during the interdisciplinary study of several polished stone tools from some Neolithic sites in Hungary. In particular, the cutting-edged tool production (axes, adzes, chisels) involves knapping at several stages of the operational-chain within an artefact's 'life cycle' - from raw material procurement, its manufacture, use, and discard. Some specific finegrained and non-siliceous raw materials, among which are mainly hornfels, "white stones" and a few greenstones, show evidence of being worked by knapping as shown by the recovery of rough-outs, flaked similarly to biface artefacts, reworked pieces during retooling attempts, and several flakes detached before and after polishing the artefact surfaces. These latter demonstrate that re-sharpening and re-working polished cutting-edged tools was a common practice within the settlements during the whole Neolithic period. These small flakes, that sometimes look like true bladelets, have been often confused with, and published as, chipped stone tools. Therefore, it is important to get a holistic view of the whole stone industry during the study of the lithic assemblages. As in the case for chert and flint in $\mathrm{N}$ Europe, which have been intensively exploited for the production of polished axes and adzes, some other lithic raw materials could be easily worked by knapping for the production of polished tools, especially micro-crystalline rocks that have technical response and physical properties very similar to true flint and chert. Moreover, there are indeed implications regarding social organization among Neolithic communities, not only from the point of view of raw material procurement. Notably, the technical capability of producing and maintaining in efficiency the polished stone tools had to be acquired by individuals belonging to each household within the community, since stone axe-adzes were polyfunctional tools for mundane and multiple tasks. Therefore, as an important means for survival, the production of stone tools, both chipped and polished, was a knowledge certainly transmitted from generation to generation, although we still have to understand the modes and social implications of the transfer in details.
\end{abstract}

Keywords: polished stone cutting edge tools; knapping; production technology; microcrystalline rocks; Neolithic; Hungary

Published by the School of History, Classics and Archaeology, University of Edinburgh ISSN: 2055-0472. URL: http://journals.ed.ac.uk/lithicstudies/ 


\section{Introduction}

The evidence gathered during the interdisciplinary study of several polished stone tools retrieved from some Neolithic sites in Hungary (Figure 1) shows that the cutting-edged tool production (axes, adzes, chisels) involves knapping at several stages of the operational sequence within the artefact's "life cycle" from raw material procurement, its manufacture, use, and discard (Inizan et al. 1992: 11-14).

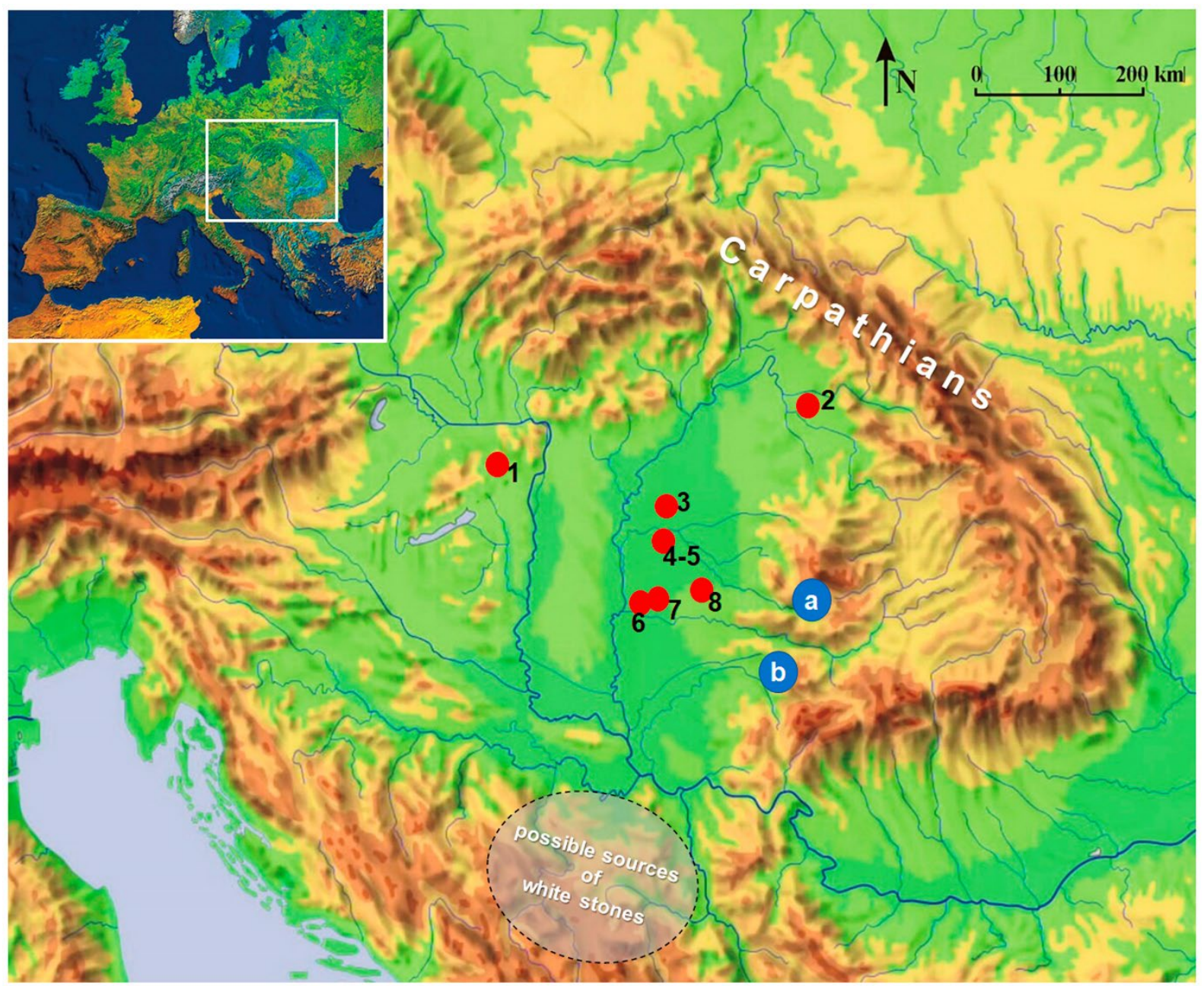

Figure 1. Map of the Carpathian Basin with the archaeological and geological localities mentioned in the text: 1: Bicske-Galagonyás; 2: Méhtelek-Nádas; 3: Ecsegfalva 23; 4-5: Szarvas and Endrőd; 6: Tápé-Lebö; 7: Hódmezővásárhely-Gorzsa; 8: Pitvaros; a (Rusca Mts.) and b (S-Apuseni Mts.): identified sources of hornfels. The possible source area of the so called "white stones" (magnesite bearing siliceous rocks and others) is marked according to the map from Antonović (1997: fig.1).

The chronology of the sampled artefacts spans from the early Neolithic (Méhtelek, Pitvaros, Ecsegfalva, Szarvas and Endrőd), the middle Neolithic (Bicske-Galagonyás), to the late Neolithic (Hódmezővásárhely-Gorzsa, Tápé-Lebő).

\subsection{Sites and materials}

Polished stone tools from the studied sites comprise adzes, axes and chisels commonly with a plano-convex, or biconvex cross section and complexly polished surfaces from sites dated to the early, middle and late Neolithic. Therefore, it is possible to observe continuity or changes in the technology of polished stone tools production and maintenance throughout the whole Neolithic period. 
Several pieces from Méhtelek-Nádas, an early Neolithic site in N-E Hungary (Figure 1: 2) show re-sharpening attempts by flaking after accidental breaking of the tool (Starnini 1994: 70, figs. 39, 47-48). In one case it was possible to refit a flake to the piece (Starnini 1994: fig. 39: 6). One specimen is particularly interesting since it was discarded after being bifacially flaked (Figure 2: A), probably due to the irregular thickness of its cross-section (Starnini 1994: fig. 48: B, 1). Moreover, the site yielded several flakes from re-sharpening or reworking of polished stone tools (Figure 2: B). A small collection of polished stone tools from Ecsegfalva 23 (Figures 1 and 3), another early Neolithic Körös Culture settlement, shows that artefacts were worked and re-worked or re-shaped by flaking, as demonstrated by the presence of flakes bearing one polished side (Starnini et al. 2007: fig. 30:1).
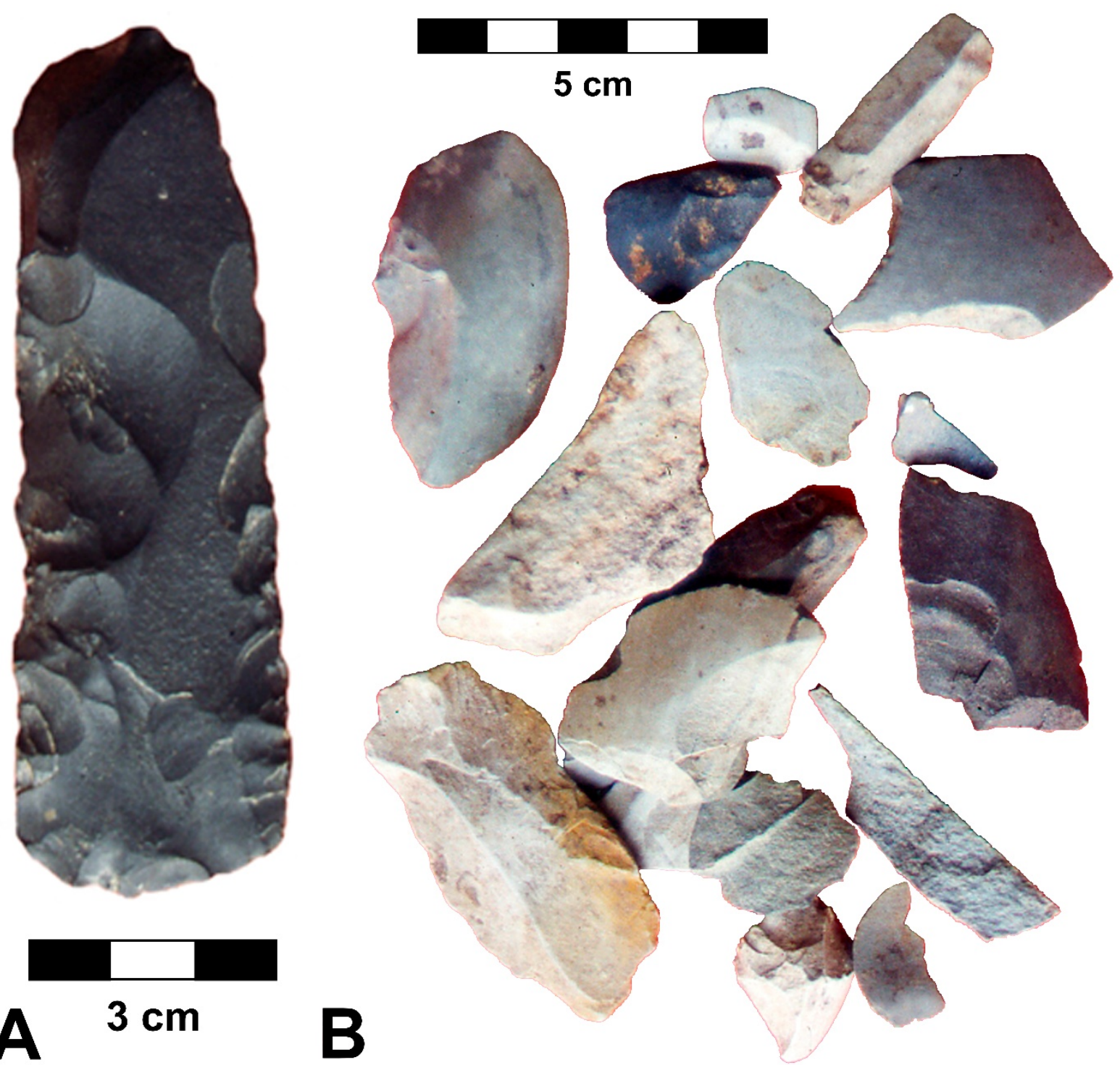

Figure 2. Méhtelek-Nádas, early Neolithic, Körös Culture: reworked polished stone tool by bifacial flaking (A); flakes from reworking polished stone tools; (B), scale in $\mathrm{cm}$. 

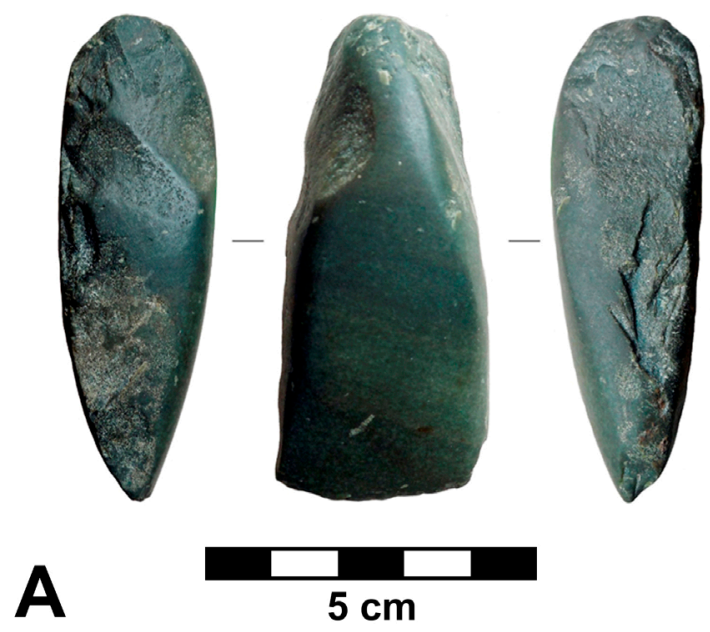

Figure 3. Hódmezővásárhely-Gorzsa, late Neolithic, Tisza Culture. A: adze blade knapped before polishing, hornfels (GOR-489); B: polished axe blade knapped after polishing and trace of “débitage par sciage” (Nougier \& Romain 1953), reworking attempt, hornfels (GOR-606).

Other studied polished tool collections are those from the early Neolithic sites of the Szarvas and Endrőd region (Figure 1: 4-5) (Starnini \& Szakmány 2000). Several pieces of microcrystalline rocks show reworking and retooling attempts by knapping the surfaces and the fractures (Starnini \& Szakmány 2000: fig. 24: 1), whilst others bear scars of knapping before polishing (Starnini \& Szakmány 2000: fig. 5, 4). Similar manufacture technology has been observed during the study of middle Neolithic, Linear Pottery assemblages from BicskeGalagonyás (Figure 1: 1), in Transdanubia (Starnini 1996: figs. 119, 120).

Recently, other polished stone collections have been studied from Pitvaros, dating to the early Neolithic, and to the late Neolithic, Tisza Culture sites of Tápé-Lebö and Hódmezővásárhely-Gorzsa (Figure 1: 6-7). The present paper will examine the evidence gathered during the interdisciplinary study of these last collections.

\section{Raw materials and methods}

Among the polished stone tool assemblages from several Hungarian Neolithic sites some specific fine-grained non-siliceous rocks show evidence of being worked by knapping before and after polishing (Figures 3 and 4 and Table 1). A similar technology and operational sequence have been documented in the Vinča Culture (Antonović 2014; Prinz 1988).
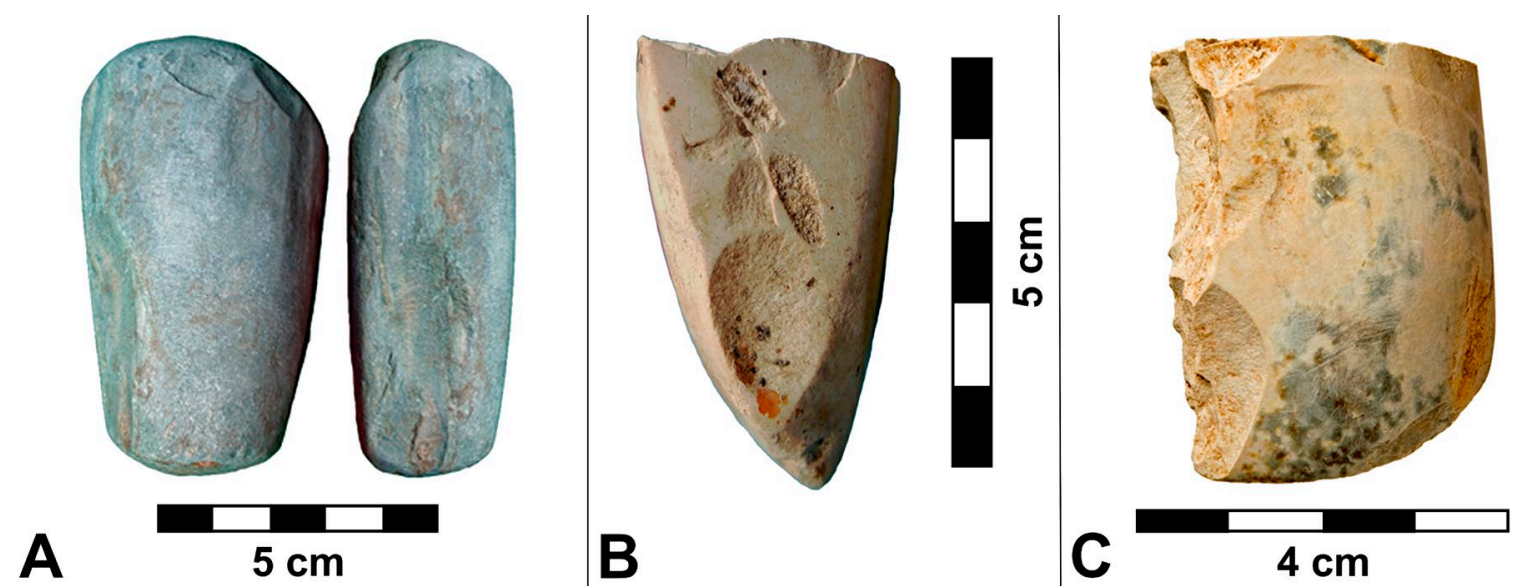

Figure 4. A: adze reused as hammerstone knapped before polishing, greenstone (PIV-5, from Pitvaros); B: adze blade fragment knapped before polishing, "white stone” (GOR-901, from Gorzsa); C: adze blade fragment knapped after polishing, “white stone” (PIV-10, from Pitvaros). 
Table 1. List of unpublished polished stone artefacts showing scars of flaking technology from Hódmezővásárhely-Gorzsa (GOR-), Tápé-Lebő (TL-) and Pitvaros (PIV-) (EN for early Neolithic; LN for late Neolithic).

\begin{tabular}{|c|c|c|c|c|}
\hline Sample & Date & Raw material & Short description & Figure \\
\hline GOR-4 & LN & hornfels & reworking flake after polishing & 5 \\
\hline GOR-94 & $\mathrm{LN}$ & hornfels & reworking flake after polishing & 5 \\
\hline GOR-140 & $\mathrm{LN}$ & hornfels & $\begin{array}{l}\text { fragment of flat plano-convex adze. Knapped before } \\
\text { polishing }\end{array}$ & - \\
\hline GOR-146 & $\mathrm{LN}$ & white stone & $\begin{array}{l}\text { fragment of plano-convex adze on flake. Knapped } \\
\text { after polishing }\end{array}$ & - \\
\hline GOR-156 & LN & hornfels & $\begin{array}{l}\text { flake of polished stone tools. Knapped before and } \\
\text { after polishing }\end{array}$ & - \\
\hline GOR-226 & $\mathrm{LN}$ & hornfels & $\begin{array}{l}\text { plano-convex adze. Knapped before and after } \\
\text { polishing }\end{array}$ & - \\
\hline GOR-227 & $\mathrm{LN}$ & hornfels & $\begin{array}{l}\text { complete plano-convex adze. Knapped before } \\
\text { polishing }\end{array}$ & - \\
\hline GOR-233 & $\mathrm{LN}$ & hornfels & small adze. Knapped before polishing. & - \\
\hline GOR-241 & $\mathrm{LN}$ & hornfels & fragment of reworking flake. Knapped after polishing & $6, A$ and $B$ \\
\hline GOR-404 & LN & white stone & $\begin{array}{l}\text { plano-convex adze. Knapped before and after } \\
\text { polishing }\end{array}$ & - \\
\hline GOR-431 & $\mathrm{LN}$ & hornfels & reworking bladelet after polishing & 5 \\
\hline GOR-439 & LN & hornfels & reworking flake after polishing & 5 and 6 \\
\hline GOR-488 & LN & white stone & $\begin{array}{l}\text { small complete shoe last chisel. Knapped before } \\
\text { polishing }\end{array}$ & - \\
\hline GOR-489 & LN & hornfels & $\begin{array}{l}\text { complete polished adze. It shows chipping before } \\
\text { polishing (polishing covers the chipping scars) }\end{array}$ & $3, \mathrm{~A}$ \\
\hline GOR-491 & $\mathrm{LN}$ & hornfels & $\begin{array}{l}\text { fragment of shoe last chisel. Knapped before and } \\
\text { after polishing }\end{array}$ & - \\
\hline GOR-494 & $\mathrm{LN}$ & hornfels(?) & $\begin{array}{l}\text { complete polished adze. Knapped before and after } \\
\text { (old damaged?) polishing }\end{array}$ & - \\
\hline GOR-501 & $\mathrm{LN}$ & hornfels & reworking flake after polishing & - \\
\hline GOR-506 & LN & white stone & $\begin{array}{l}\text { fragment of flat axe on flake. Knapped bifacially } \\
\text { before polishing. Rough out? }\end{array}$ & - \\
\hline GOR-509 & $\mathrm{LN}$ & hornfels & shoe-last chisel pre-form. Knapped before polishing & - \\
\hline GOR-523 & LN & hornfels & $\begin{array}{l}\text { plano-convex adze. Knapped before and after } \\
\text { polishing }\end{array}$ & - \\
\hline GOR-598 & $\mathrm{LN}$ & white stone & $\begin{array}{l}\text { fragment of flat axe on flake. Chipped before and } \\
\text { after polishing }\end{array}$ & - \\
\hline GOR-606 & $\mathrm{LN}$ & hornfels & $\begin{array}{l}\text { polished stone tools in reworking. Knapped after } \\
\text { polishing. Groove cut in the middle }\end{array}$ & $3, \mathrm{~B}$ \\
\hline GOR-636 & $\mathrm{LN}$ & white stone & $\begin{array}{l}\text { fragmentary plano-convex adze. Knapped before and } \\
\text { after polishing }\end{array}$ & - \\
\hline GOR-645 & LN & amphibolite & reused flake as chisel. It is polished after flaking & - \\
\hline GOR-646 & LN & white stone & $\begin{array}{l}\text { fragment of shoe last chisel. Knapped before and } \\
\text { after polishing }\end{array}$ & - \\
\hline GOR-715 & LN & white stone & small axe on flake. Chipped after polishing & - \\
\hline GOR-719 & LN & hornfels & $\begin{array}{l}\text { fragment of plano-convex adze. Knapped before and } \\
\text { after polishing }\end{array}$ & - \\
\hline GOR-796 & LN & hornfels & broken plano-convex adze. Knapped after polishing & - \\
\hline GOR-823 & LN & white stone & $\begin{array}{l}\text { complete plano-convex adze. Chipped before and } \\
\text { after polishing }\end{array}$ & - \\
\hline
\end{tabular}




\begin{tabular}{|c|c|c|c|c|}
\hline Sample & Date & Raw material & Short description & Figure \\
\hline GOR-834 & LN & white stone & $\begin{array}{l}\text { small plano-convex adze. It was chipped } \\
\text { before polishing }\end{array}$ & - \\
\hline GOR-844 & LN & hornfels & reworking flake after polishing & 5 \\
\hline GOR-846 & LN & hornfels & reworking flake after polishing & 5 \\
\hline GOR-900 & LN & white stone & $\begin{array}{l}\text { cutting edge fragment of an axe. } \\
\text { Chipped after polishing }\end{array}$ & - \\
\hline GOR-901 & LN & white stone & $\begin{array}{l}\text { fragment of shoe last chisel. Knapped } \\
\text { before polishing }\end{array}$ & $4, B$ \\
\hline GOR-902 & LN & hornfels & reworking flake after polishing & 5 \\
\hline GOR-925 & LN & hornfels & $\begin{array}{l}\text { fragment of plano-convex adze cutting } \\
\text { edge. Knapped before polishing }\end{array}$ & - \\
\hline GOR-938 (GO-13) & LN & hornfels & $\begin{array}{l}\text { fragment of shoe last chisel. Knapped } \\
\text { before and after polishing }\end{array}$ & - \\
\hline GOR-1013 & LN & hornfels & reworking flake after polishing (82.1.8) & 5 \\
\hline GOR-1019 & LN & hornfels & $\begin{array}{l}\text { fragment of plano-convex adze. } \\
\text { Knapped after polishing }\end{array}$ & - \\
\hline GOR-1027 & LN & hornfels & reworking flake after polishing & 5 \\
\hline GOR-1029 & LN & hornfels & reworking flake after polishing & 5 \\
\hline GOR-1030 & LN & white stone & reworking flake after polishing & - \\
\hline GOR-1034 & LN & hornfels & chisel Knapped before polish & - \\
\hline GOR-1036 & LN & hornfels & reworking flake before polishing & 5 \\
\hline GOR-1038 & LN & hornfels & reworking flake after polishing & 5 \\
\hline GOR-1041 & LN & Mecsek radiolarite & reworking flake after polishing & - \\
\hline GOR-1042 & LN & hornfels & reworking flake before polishing & - \\
\hline TL-5 & LN & hornfels & $\begin{array}{l}\text { complete polished adze. It shows } \\
\text { chipping before polishing (polishing } \\
\text { covers chipping scars). Damaged }\end{array}$ & - \\
\hline PIV-5 & EN & greenstone & $\begin{array}{l}\text { adze reused as hammerstone. Knapped } \\
\text { before polishing }\end{array}$ & $4, A$, and 8 \\
\hline PIV-10 & EN & white stone & $\begin{array}{l}\text { adze blade fragment. Knapped after } \\
\text { polishing }\end{array}$ & $4, C$ \\
\hline
\end{tabular}

This technological evidence is shown by the recovery of rough-outs, flaked similarly to bifacial artefacts, reworked pieces during retooling attempts, and the presence of several flakes detached before and after polishing the artefact surfaces with marked percussion bulbs due to intentional, controlled hard hammering (Figure 5). Therefore, it is possible to distinguish between accidental breaks and intentional flaking.

These latter demonstrate that re-sharpening and re-working polished cutting-edged tools was a common practice within the settlements during the whole Neolithic. These knapped byproducts, that sometimes look like true blades and flakes, may cause problems in recognition and classification (Prinz 1988: 257). Therefore, they might have been often confused with, and published as, chipped stone artefacts (Kaczanowska \& Kozłowski 1987: fig. 3, 1).

Raw materials of some artefacts knapped before and after polishing have been determined by means of petroarchaeometry (petrographic analysis from thin section, electronmicroscopic analysis by Scanning Electron Microscopy-Energy Dispersive Using X-Ray (SEM-EDX), chemical analysis by Prompt gamma-ray activation analysis (PGAA). 


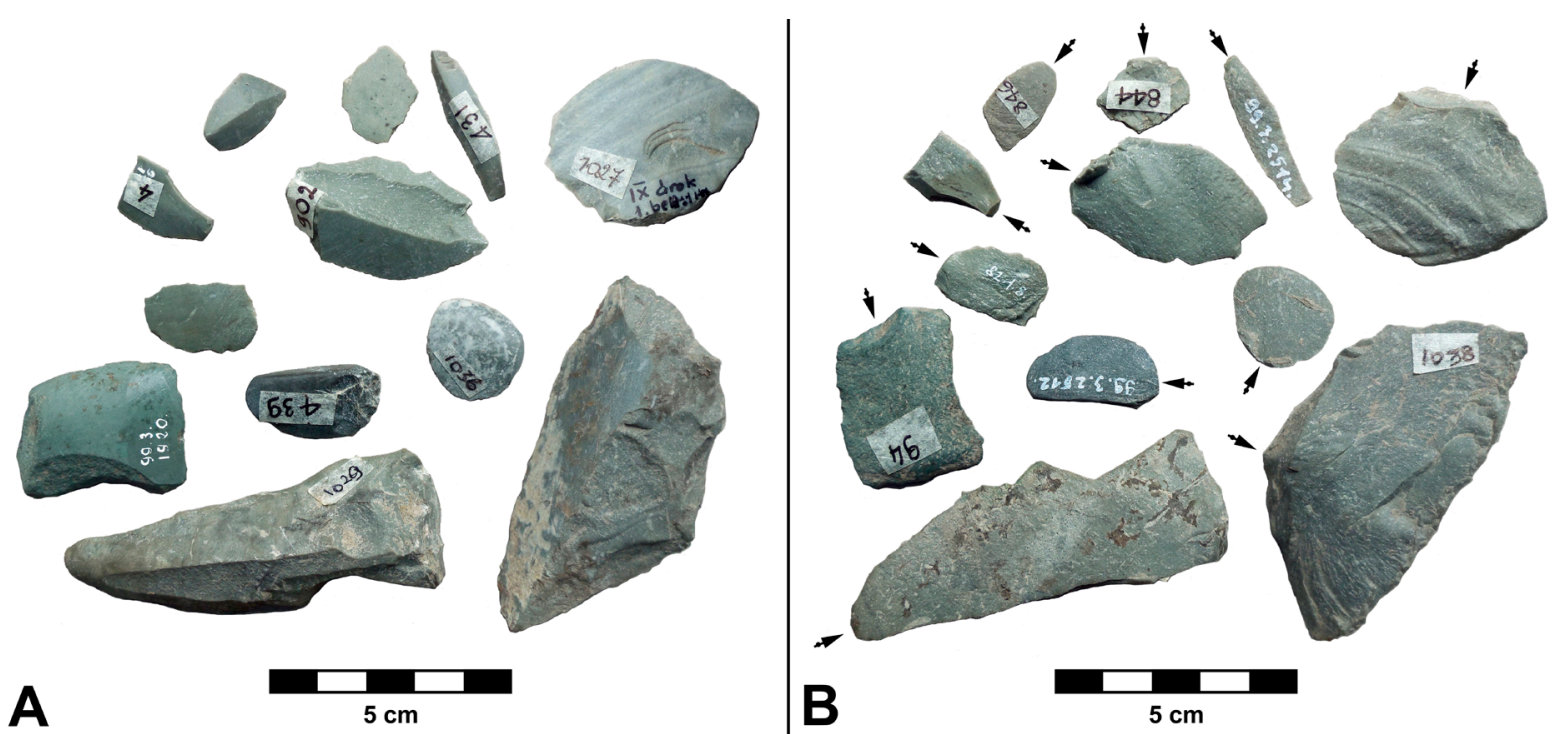

Figure 5. Hódmezővásárhely-Gorzsa, late Neolithic, Tisza Culture: knapped flakes and bladelets with bulb of percussion (black arrows), dorsal (A) and ventral (B) views, from hornfels polished stone tools.

Identified raw materials are all fine-grained rocks, among which especially represented are hornfels (Figure 6), "white stones" (Antonović 1997; Antonović et al. 2005) and more rarely greenstones (greenschists and amphibolites) and others (radiolarite, siliceous siltstone (Szakmány 1994)) that show evidence of being worked by knapping.

The hornfels is a very fine-grained, hard and tenacious, homogeneous greenish-grey, greyish-green or pale-grey rock, consisting of diopside, feldspar (K-feldspar or Ca-rich plagioclase), and occasionally less biotite, and scapolite (Figure 6). Accessory constituents are highly variable, the most common are sphene, apatite, allanite, zircon, titanite and pyrrhotite (Szakmány et al. 2016).

The "white stone" rock, which is petrologically a magnesitic silicite, consists of predominantly microcrystalline quartz with small holes filled by magnesite, and occasionally calcite. As accessories few rutile and zircon occur (Figure 7).

The raw material of the greenstone artefact from PIV-5 is a greenschist-(low grade amphibolite) rock, consisting of: epidote, actinolite, Na-rich plagioclase, quartz, small amount of fine grained titanite and few zircon crystals (Figure 8).

The provenances localities of the hornfels have been recognized in the Rusca Mts. and the S-Apuseni Mts (Figure 1: a-b) (Starnini et al. 2015; Szakmány et al. 2016), whilst the provenance area of "white stone" rocks is located in a larger territory to the South of the Carpathian Basin (Figure 1), in present Serbia (Antonović 1997: fig. 1), the core area of the Vinča Culture. A possible provenance of the greenstones is the Apuseni Mts., but the precise location of the possible outcrop has not been established until now. 

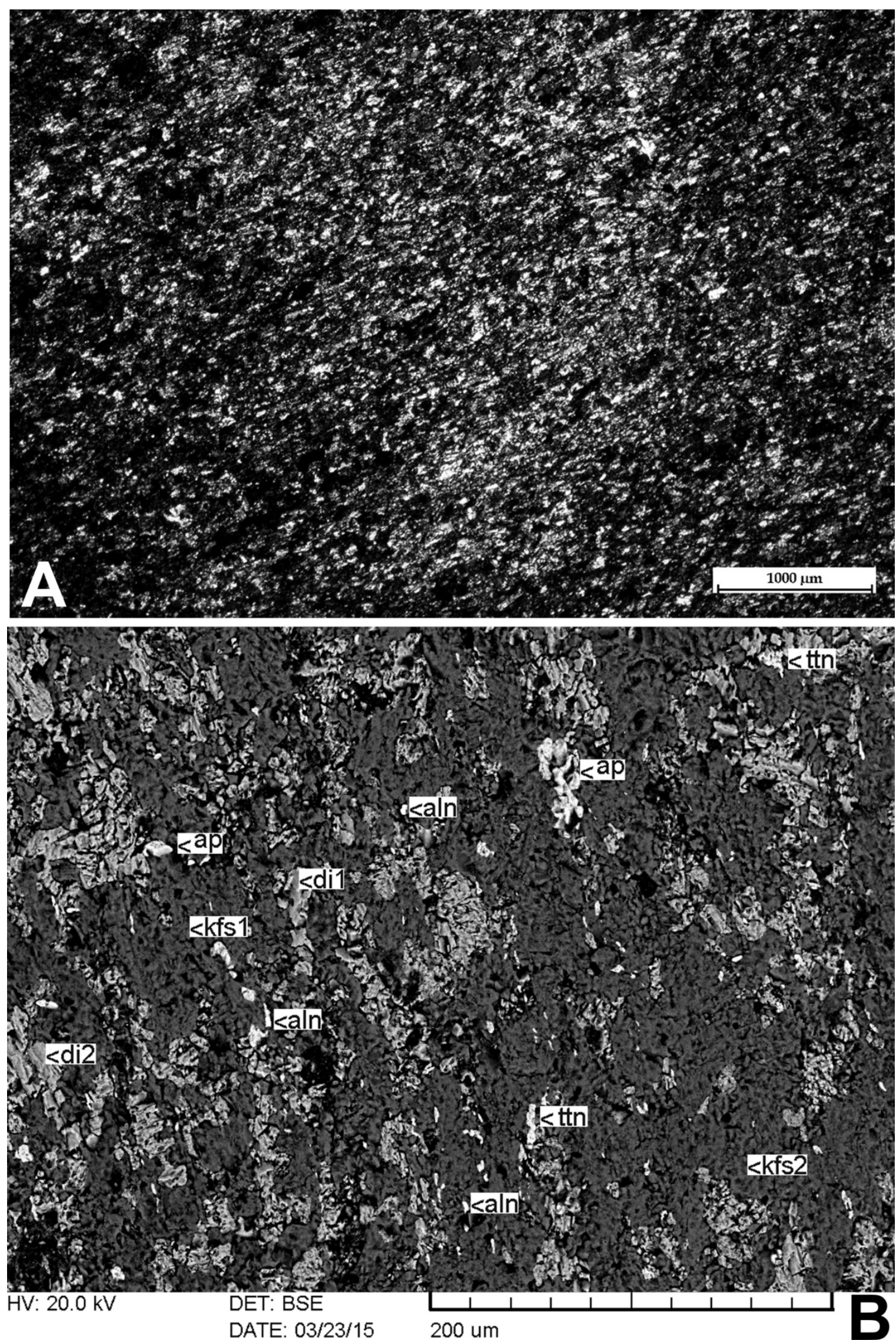

Figure 6. Late Neolithic hornfels polished stone tool (GOR-241, Gorzsa tell): A, thin section microphotographs (modified from Szakmány et al. (2016)); B, Back-Scattered Electron (BSE) image of the same sample: aln = allanite, ap = apatite, di1 \& di2 = diopside, kfs1 \& kfs2 = K-feldspar, ttn = titanite. 


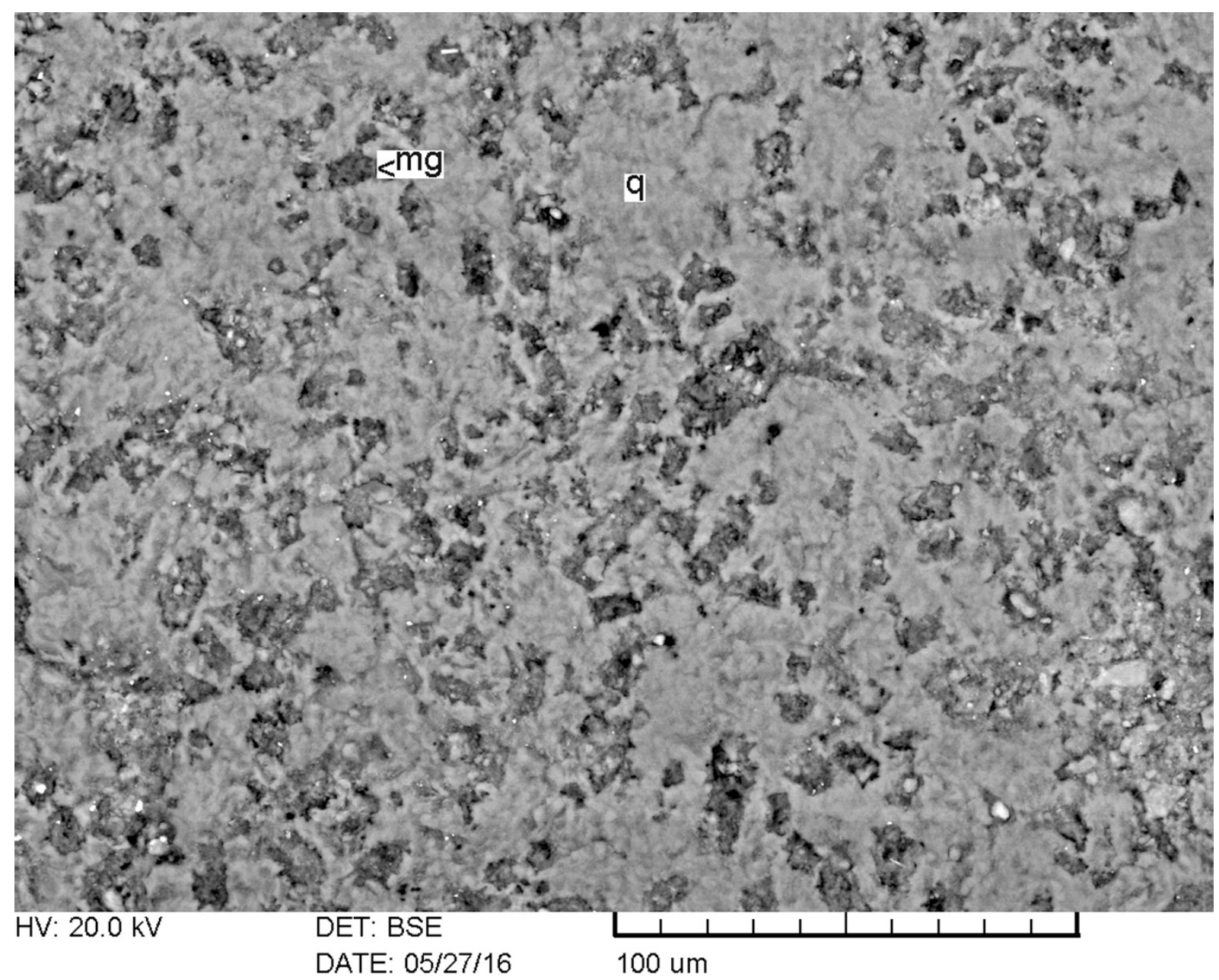

Figure 7. BSE image of Neolithic white stone polished tool (GOR-293, Gorzsa tell): q for quartz, Mg for magnesite. 


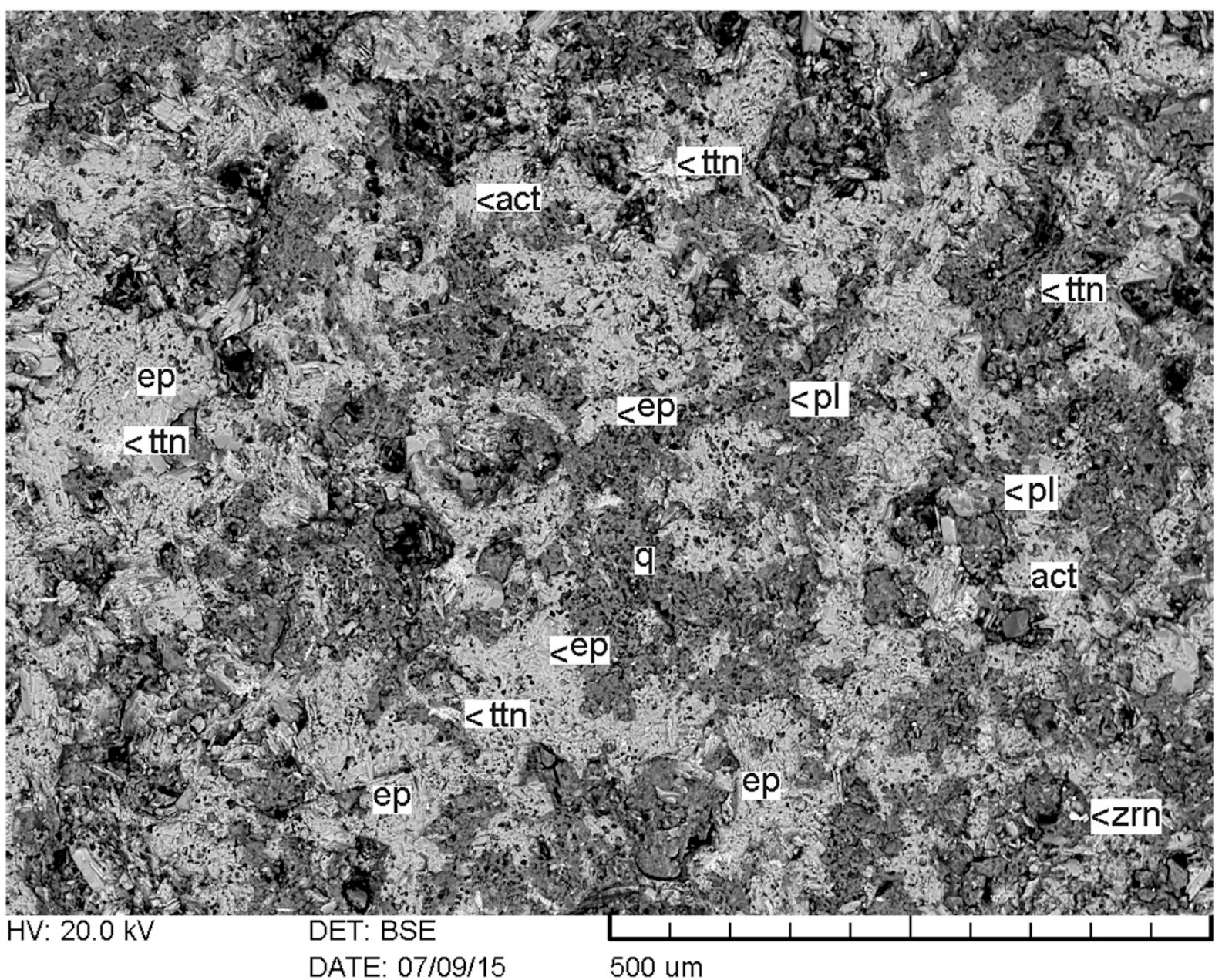

Figure 8. BSE image of an early Neolithic greenstone polished tool (PIV-5, Pitvaros): act for actinolite, ep for epidote, pl for plagioclase, q for quartz, th for titanite, zrn for zircon.

\section{Interpretations of the data}

Our data gathered during several years of analysis of polished stone tools from different Neolithic sites of the Carpathian Basin in Hungary show that this craftsmanship is quite a conservative one, both in terms of technology of tool production and maintenance, and raw material choice. Since the early Neolithic, cutting-edged tools employed in wood working have been obtained shaping the rough-outs by knapping different micro-crystalline rocks, first of all hornfels and "white stones". After this step, the operative chain employed grinding and polishing with abrasive media on the whole surfaces of the tools. Some authors, taking into account the operative chain used by lapidary artisans for gemstones, suggest to employ the term "polishing" only for those cases when surfaces are brought to a high shining gloss (Prinz 1988: 257). However, the general term "polished stone tools" is usually employed in archaeological literature to distinguish the peculiar surface finish of wood working, cuttingedged tools (axes, adzes, chisels) from that of other macro-lithic tools such as grinding stones, hammerstones, hand-stones etc. (Adams et al. 2009). In Europe there are indeed cases of stone axe-heads with whole polished surfaces to a glassy, high sheen, but they are always considered as "prestige" items, most probably embedding personal status or symbolic meanings (Pétrequin et al. 2012: 17-22; 2017a: 14-23; 2017b).

Other working techniques have been seldom observed in our assemblages, namely the débitage par sciage (Nougier \& Romain 1953) for cutting and splitting the pieces, starting from the early Neolithic (Endrőd 119) (Starnini \& Szakmány 1998: fig. 8: 1-3) until the late 
Neolithic (Figure 3: B). This technique, involving sawing to produce a straight groove along which the piece is then snapped off into two pieces was also used at Divostin, a Neolithic site in central Serbia with a cultural sequence spanning from Starčevo to Vinča periods (Prinz 1988: 257).

This production technology is quite different from the western European tradition that employs pecking technique after shaping the rough-outs by knapping and usually finishes only the cutting-edge part with polishing (D’Amico \& Starnini 2012). This different tradition may be conditioned by the technical response of the raw materials employed, namely Alpine High-Pressure meta-ophiolites (Váczi et al. 2019), certainly harder and tougher to work than hornfels and the other micro-crystalline rocks employed in S-E Europe. In the Carpathian Basin, the same knapping technology employed before and after polishing the surfaces for the production and maintenance of adze and axe heads during the early Neolithic is observed also during the middle and late Neolithic.

Therefore, it might be considered a quite conservative tradition, most probably representing the optimal technology for processing the commonest S-E European stone raw materials employed in the polished stone tool production.

\section{Conclusions, significance, opinions}

This research shows that it is important to get a holistic view of the whole stone industry during the study of the lithic assemblages. As is the case for chert and flint in $\mathrm{N}$ Europe, which have been intensively exploited for the production of polished axes and adzes, some other lithic raw materials could be easily worked by knapping for the production of polished tools too, especially some micro-crystalline non-siliceous rocks that have technical response and physical properties very similar to true flint and chert.

Moreover, there are indeed implications regarding social organization among Neolithic communities, not only from the point of view of raw material procurement.

Notably, the technical capability of producing and maintaining in efficiency the polished stone tools had to be acquired by individuals belonging to each household within the community, since stone axe-adzes were polyfunctional tools for mundane and multiple tasks.

Therefore, as an important means for survival, the technology for the production of both chipped and polished stone tools was a know-how certainly transmitted from generation to generation, although we still have to understand in full details the modes and social implications of its transfer.

\section{Acknowledgements}

This research was developed thanks to 1-month postdoctoral research scholarship at the Department of Petrology and Geochemistry, Eötvös Loránd University granted for the A.Y. 2018-2019 to one of the authors (ES) by the Tempus Public Foundation-Hungary. This research was supported by the Hungarian Scientific Research Fund (OTKA) K 100385 and K 131814 (P.I.: Zsolt Kasztovszky).

\section{Data accessibility statement}

The data used here are from the ownership of the authors, and the others are cited. The data presented in this study are available on request from the authors. 


\section{References}

Adams, J., Delgado, S., Dubreuil, L., Hamon, C., Plisson, H. \& Risch, R. 2009, Functional analysis of macro-lithic artefacts: A focus on working surfaces. In: Non-Flint Raw Material Use in Prehistory: Old prejudices and new directions / L'utilisation préhistorique de matières premières lithiques alternatives : Anciens préjugés, nouvelles perspectives, Session C77, (Sternke, F., Eigeland, L. \& Costa, L.-J., Eds.), Proceedings of the XV World Congress of the International Union for Prehistoric and Protohistoric Sciences, Actes du XV Congrès Mondial de l’Union Internationale des Sciences Préhistoriques et Protohistoriques, Vol. 11, BAR International Series Vol. 1939, British Archaeological Reports, Oxford: p. 43-66.

Antonović, D. 1997, Use of Light White Stone in the Central Balkans Neolithic. Starinar, 48: 33-39.

Antonović, D. 2014, Manufacturing of Stone Axes and Adzes in Vinča Culture. In: Archaeotechnology: Studying technology from prehistory to the Middle Ages, (Vitezović, S. \& Antonović, D., Eds.), Serbian Archaeological Society, Belgrade: p. 7788.

Antonović, D., Resimić-Sarić, K. \& Cvetković, V. 2005, Stone raw materials in the Vinča Culture: Petrographic analysis of assemblage from Vinča and Belovode. Starinar, 55: 53-66. doi:10.2298/sta0555053a

D’Amico, C. \& Starnini, E. 2012, La production d'outils de pierre en Italie du Nord vue depuis l'atelier de Rivanazzano (Province de Pavie, Lombardie): matières premières et chaîne opératoire. In: Produire des haches au Néolithique: de la matière première à l'abandon, Actes de la table ronde de S. Germain- en-Laye (De Labriffe, P.-A. \& Thirault, E., Eds.), Séances de la Société Préhistorique Française, Vol. 1, Société préhistorique française, Paris: p. 17-25. (in French) ("The production of stone implements in Northern Italy from the point of view of the Rivanazzano workshop (Pavia Province, Lombardy”): Raw materials and chaîne opératoire”) URL: http://www.prehistoire.org/offres/file_inline_src/515/515_P_29974_2.pdf

Inizan, M.L., Roche, H. \& Tixier, J. 1992, Technology of Knapped Stone. Préhistoire de la Pierre Taillée. Vol. 3. Cercle de Recherches et Études Préhistoriques and Centre National de la Recherche Scientifique, Meudon, 127 p.

Kaczanowska, M. \& Kozłowski, J. K. 1987, «Barbotino» (Starčevo-Körös) and Linear complex: Evolution or independent development of lithic industries? Arheološki Radovi i Rasprave, 10: 25-52.

Nougier, L.-R. \& Romain, R. 1953, Le débitage par sciage dans le «Néolithique pyrénéen». Bulletin de la Société préhistorique française, 50 (1-2): 54-60. (in French) ("The débitage par sciage in the Pyrenees Neolithic”) doi:10.3406/bspf.1953.2994

Pétrequin, P., Cassen, S., Errera, M., Klassen, L., Sheridan, A. \& Pétrequin, A.-M. (Eds.) 2012, Jade. Grandes Haches Alpines du Néolithique Européen. Ve et IVe Millénaires av. J.-C. Vol. JADE 1 \& 2, Presses universitaires de Franche-Comté et Centre de recherche archéologique de la vallée de l'Ain, Besançon, 2261 p. (in French) ("Jade. Large Alpine Axes of the European Neolithic. $5^{\text {th }}$ and $4^{\text {th }}$ Millennium BC”) 
Pétrequin, P., Gauthier, E. \& Pétrequin, A.-M., (Eds.) 2017a, Jade. Objets-signes et interprétations sociales des jades alpins dans l'Europe néolithique. vol. 17, Dynamiques territoriales, 9 Vol. JADE 3 \& 4. Presses universitaires de Franche-Comté et Centre de recherche archéologique de la vallée de l'Ain, Besançon, 1466 p. (in French) ("Jade. Symbolic objects and social interpretations of Alpine jades in Neolithic Europe“) URL: https://hal.archives-ouvertes.fr/hal-01516594

Pétrequin, P., Pétrequin, A.-M., Gauthier, E. \& Sheridan, A. 2017b, Alpine Jades: From Scientific Analysis to Neolithic Know-How. In: The Exploitation of Raw Materials in Prehistory: Sourcing, Processing and Distribution (Pereira, T., Terradas, X. \& Bicho, N., Eds.), Cambridge Scholars Publishing, Newcastle upon Tyne: p. 354-367.

Prinz, B. 1988, The Ground Stone Industry from Divostin. In: Divostin and Neolithic of Central Serbia, (McPherron, A. \& Srejović, D., Eds.), Narodni muzej Kragujevac and Department of Anthropology, University of Pittsburgh, Pittsburgh and Kragujevac: p. 255-300.

Starnini, E. 1994, Typological and technological Analysis of the Körös Culture Chipped, Polished and Ground stone assemblages of Méhtelek-Nádas (N-E Hungary). Atti della Società per la Preistoria e Protostoria della regione Friuli Venezia-Giulia, 8: 29-96.

Starnini, E. 1996, The stone artefacts. In: Excavations at Bicske Galagonyás. Part III. The "Notenkopf” and Sopot-Bicske Cultural phases, (Makkay, J., Starnini, E. \& Tulok, M., Eds.), Quaderni della Società per la Preistoria e Protostoria della Regione FriuliVenezia Giulia, Trieste: p. 151-219.

Starnini, E. \& Szakmány, Gy. 2000, The lithic industry of the Neolithic sites of Szarvas and Endröd (south-east Hungary): Techno-typological and archaeometrical aspects. Acta Archaeologica Academiae Scientiarum Hungaricae, 50: 279-342.

Starnini, E., Szakmány, G. \& Whittle, A. 2007, Polished, ground and other stone artefacts. In: The Early Neolithic on the Great Hungarian Plain: Investigations of the Körös culture site of Ecsegfalva 23, Co. Békés (Whittle, A., Ed.), Varia Archaelogica Hungarica (VAH), Budapest: p. 667-676.

Starnini, E., Szakmány, G., Józsa, S., Kasztovszky, Z., Szilágyi, V., Maróti, B., Voytek, B. \& Horváth, F. 2015, Lithics from the Tell Site Hódmezővásárhely-Gorzsa (Southeast Hungary): Typology, Technology, Use and Raw Material Strategies during the Late Neolithic (Tisza Culture). In: Neolithic and Copper Age between the Carpathians and the Aegean Sea; Chronologies and Technologies from the 6th to the 4th Millennium $B C E$ (Hansen, S., Raczky, P., Anders, A. \& Reingruber, A., Eds.), Archäologie in Eurasien Vol. 31, Habelt Verlag, Bonn: p. 105-128.

Szakmány, G. 1994, Appendix 3, Thin section analysis of some rock samples from Méhtelek In: Typological and technological Analysis of the Körös Culture Chipped, Polished and Ground stone assemblages of Méhtelek-Nádas (N-E Hungary) (Starnini, E., Ed.). Atti della Società per la Preistoria e Protostoria della regione Friuli Venezia-Giulia, Vol. 8, Società per la Preistoria e Protostoria della regione Friuli Venezia-Giulia, Triestre: p. 93-94.

Szakmány, G., Józsa, S., Bendő, Z., Kasztovszky, Z. \& Horváth, F. 2016, Magyarországon előkerült hornfels (mész-szilikát szaruszirt) anyagú csiszolt kőeszközök nyersanyaglelöhelyének felkutatása. Archeometriai Mühely, 13(1): 43-54. (in Hungarian) ("Discovering the provenance of hornfels polished stone tools in Hungary") URL: http://www.ace.hu/am/2016_1/AM-2016-1-SzGy.pdf 
Váczi, B., Szakmány, G., Starnini, E., Kasztovszky, Z., Bendő, Z., Nebiacolombo, F.A., Giustetto, R. \& Compagnoni, R. 2019, Characterization of HP meta-ophiolite boulders and cobbles from northern Italy primary outcrops and secondary deposits, as possible raw material sources for the production of "greenstone" prehistoric tools: Petrographic investigation and archaeological assessment. European Journal of Mineralogy, 31(5-6): 905-917. doi:10.1127/ejm/2019/0031-2859 